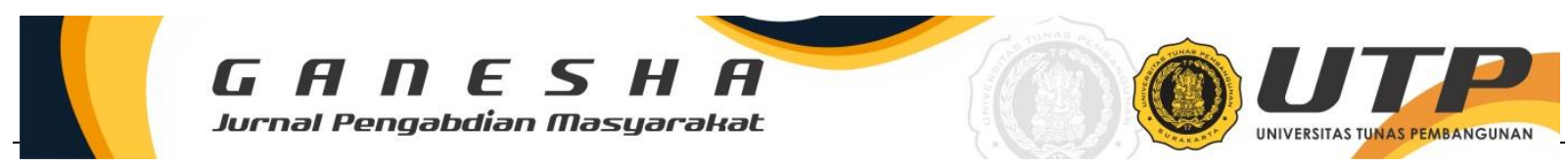

\title{
INOVASI PRODUK OLAHAN KEDELE PADA UMKM KEDELE CRYSPY ERTE
}

\author{
Asroful Kadafi*1 ${ }^{* 1}$ Suharni $^{2}$, Ratih Christiana ${ }^{3}$ \\ ${ }^{1,2,3}$ Universitas PGRI Madiun \\ Email: asrofulkadafi@unipma.ac.id
}

\begin{abstract}
Abstrak
Usaha Mikro Kecil dan Menengah (UMKM) pada masa pandemic Covid-19 adalah salah satu sektor ekonomi yang terdampak. Masalah ini juga dialamai oleh Mitra Program Pengabdian Masyarakat kami. UMKM mitra kami yang memproduksi olahan kedelai, memiliki beberapa permasalahanj diantaranya: pertama: produksi dilakukan masih dengan cara tradisional, kedua: belum memiliki ijin usaha, dan ketiga: belum memiliki ijin PIRT. Untuk menyikapi masalah ini, perlu adala solusi membantu permasalahan Mitra. Dari permasalahan yang ada Tim Pengabdian Masyarakat (Abdimas) merencana metode pelaksanaan diantaranya: melaksanakan pelatihan dan pendampingan kepada mitra (pengolahan, pengemasan dan pemasaran), dan melakukan pendampingan pengurusan ijin administrasi mitra. Hasil yang dicapai dari program ini diantaranya: Usaha Mitra mengalami perubahan yang cukup siginifikan, ditandai dari olahan produk kedele yang dulunya hanya kedele goreng dikemas dalam kemasan sederhana sekarang menjadi olahan kedele krispi yang jauh memiliki nilai ekonomi tinggi, diperolehnya Ijin PIRT dan Ijin Usaha.
\end{abstract}

Kata kunci: produk kedele, UMKM

\begin{abstract}
UMKM during the Covid-19 pandemic was one of the economic sectors affected. This problem is also experienced by our Community Service Program Partners. Our partner MSMEs that produce processed soybeans, have several problems including: first: production is still carried out traditionally, second: does not have a business permit, and third: does not have a PIRT permit. To address this problem, a solution is needed to help Partner's problems. From the existing problems, the Community Service Team (Abdimas) plans implementation methods including conducting training and mentoring to partners (processing, packaging, and marketing) and providing assistance in the management of partner administrative permits. The results achieved from this program include: Partners' businesses have undergone significant changes, marked from processed soy products which were previously only fried soybeans packaged in simple packages, now processed crispy soybeans which have far high economic value, obtaining PIRT permits and business permits.
\end{abstract}

Keywords: Soybean Products, UMKM

\section{PENDAHULUAN}

Kondisi pandemi Covid-19 yang melanda dunia sejak akhir tahun 2019 sangat mempengaruhi perekonomian masyarakat. Irham (2020) menyatakan jika UMKM menjadi salah satu sektor yang rentan mengalami kerugian pada masa pandemi. Namun, dilain pihak pemerintah sangat berharap jika UMKM dapat menjadi tumpuan menyelematkan perekonomian Negara ini. Barangkat dari masalah ini tim Abdimas kami bermitra dengan salah satu UMKM yang berada di Ponorogo dengan tujuan untuk mengembangkan UMKM mitra ditengah pandemi. UMKM yang bermitra dengan kami adalah UMKM "Kedelai Cesyspy Erte". UMKM ini milik saudara Okta Nur Wahyu Pratama yang beralamat di Jl. Indra Giri Nomor 7 Desa Nambak Kecamatan Bungkal Ponorogo. Produk yang dihasilkan dari mitra yaitu berupa olahan kedelai, seperti: tempe, kedelai goreng dan kripik tempe. Produk yang dihasilkan selama ini diolah dan dipasarkan dengan secara tradisional. Dari rutinitas yang telah lama digeluti ini, pendapat yang didapatkan oleh mitra tidak menentu. Selama ini mitra memasarkan produknya ke pasar tradisional dan melayani pesanan ke tetangga terdekat. Olahan yang dihasilkan oleh mitra rasanya cukup enak, namun beberapa 
konsumen sering memberikan saran, diantaranya: kemasan bisa dipercantik dan dijaga kebersihannya, agar lebih meyakinkan konsumen disarankan segera mengurus perijinan usaha dan ijin dari dinas kesehatan. Permasalahan yang dialami mitra ini, dikarenakan karena kurangnya informasi dan pendampingan dari pihak terkait untuk mengembangkan sebuah usaha.

Lokasi mitra berada pada lingkungan padat penduduk yang cukup strategis. Lokasi pasar dari rumah mitra hanya berjarak sekitar $1 \mathrm{~km}$. Masyarakat sekitar kebanyakan bekerja serabutan sebagai buruh tani, sehingga juga perlu mendapat perhatian. Melalui program ini mitra diharapkan bisa mengembangkan usahanya yang berdampak pada pengahasilan mitra dan juga pada meningkatnya perekonomian lingkungan sekitar. Jika usaha dari mitra berkembang tidak menutup kemungkinan mitra akan memberi peluang pekerjaan bagi masyarakat sekitar untuk menambah pendapatan mereka.

Dari temuan di atas, dapat menunjukan jika mitra kami memiliki tiga permasalahan utama yang ada, antara lain: pertama, proses produksi yang dilakukan mitra dilakukan secara tradisional, kedua, pengemasan produk pemasaran yang dilakukan mitra belum maksimal, dan ketiga, Belum ada perijinan resmi dari pihak terkait. Dari ketiga permasalahan ini, telah disepakati bersama antara pengusul dan mitra permasalahan prioritas utama yang akan diselesaikan bersama. Permasalahan pertama, yaitu pemberian alat serta pelatihan dan pendampingan pembuatan olahan kedelai. Permasalahan kedua, pelatihan pengemasan dan pemasaran secara online. Permasalahan ketiga: pendampingan pengurusan perijinan pada pihak terkait.

\section{METODE}

Program pengabdian ini ditujukan untuk membantu mengatasi permasalahan mitra yang sudah disampaikan pada bagaian pendahuluan. Pelaksanaan program ini dimulai pada Bulan Agustus 2020 hingga Oktober 2020. Untuk memaksimalkan program Abdimas, Tim memprioritaskan pada penyelesaian permasalahan utama yang dihadapi mitra yaitu: Permasalahan pertama, yaitu produksi yang dilakukan secara tradisional. Permasalahan kedua, pengemasan dan pemasaran. Dan permasalahan ketiga terkait perijinan administrasi usaha.

Adapun rencana pelaksanaan program ini adalah sebagai berikut:

a. Melakukan kegiatan identifikasi atau Analisa awal pada mitra untuk memastikan pokok permasalahan sebenarnya yang dialami mitra. Dan solusi yang akan diberikan sesuai dengan permasalahan yang ada.

b. Melaksanaan sosialiasi dan Forum Group Discusion (FGD) antara mitra, professional, dan pemerintah setempat. Langkah ini dilaksanakan untuk memastikan kelayakan solusi yang ditawarkan dan kesiapan mitra untuk mengembangkan usaha yang dimiliki. Dalam FGD ini disepakati nama usaha yang akan dijadikan nama resmi UMKM (tercermin dalam desain logo UMKM dan kemasan produk). Selain nama, pada forum ini juga disepakai jenis olahan kedelai crispy yang menjadi fokus pertama pada program ini. Dalam forum ini juga dijadikan media sosialiasi kepada pihak terkait untuk memberikan kejelasan program Abdimas.

c. Pengadaan sarana dan prasarana pengolahan kedelai, yang belum dimiliki mitra sesuai temuan idetifikasi masalah mitra 
d. Pelatihan dan pendampingan prosedur atau cara aplikasi peralatan baru bagi mitra, untuk melakukan perubahan cara kerja mitra, dari sebekumnya pengolahan secara tradisional menjadi cara modern.

e. Pendampingan pembuatan olahan kedelai crispy secara modern pada mitra, untuk memastikan mitra benar-benar mampu mengoperasikan alat dan memproduksi kedelai krispi secara mandiri.

f. Pelatihan dan pendampingan strategi promosi serta media promosi, untuk meningkatkan jumlah penjualan prudak olahan mitra, termasuk pelatihan menjalin relasi dengan mitra kerja.

g. Pendampingan pengurusan perijinan bersama mitra, adapun ijin yang akan diurus yaitu: ijin PIRT untuk memastikan keamanan dan kesehatan produk olahan makanan mitra, dan ijin UMKM.

h. Evaluasi kegiatan secara keseluruhan, untuk melihat ketercaian program.

i. Tindak lanjut/follow up dengan melaksanakan monitoring dan evaluasi, yang dilaksanakan setiap 2 minggu untuk memastikan keberlangsungan program dan melihat apakah mitra memiliki permasalahan selama menjalankan usahannya.

Program pengabdian ini merencanakan membuat daftar chek untuk melihat tingkat keberhasilan program. Daftar cek ini di isi oleh supervisor, pada program ini dilaksanakan oleh LPPM Universitas PGRI Madiun selaku pihak penanggung jawab program Abdimas ini. Adapun daftar chek list penilaian program ini disajikan pada tabel 1.

Tabel 1. Chek List Monitoring Ketercapaian Program

\begin{tabular}{lll}
\hline \multirow{2}{*}{ No } & \multicolumn{1}{c}{ Luaran yang direncanakan } & Ketercapaian \\
\hline 1 & Nama UMKM & Tidak \\
2 & Desain logo dan kemasan produk UMKM \\
3 & Hak Cipta (Buku Panduan Inovasi Produk Bahan Dasar Kedelai) & \\
4 & Ijin PIRT & \\
5 & Ijin UMKM & \\
6 & Produk baru olahan kedelai \\
7 & Peningkatan produksi olahan kedelai \\
8 & Melakukan pemasaran secara inovatif (online dan offline) \\
\hline
\end{tabular}

\section{HASIL DAN PEMBAHASAN}

Capaian atau hasil yang dicapai dari program setelah melalui rangkaian tahapan seperti yang dijelaskan dalam poin metode, capaian program ini: pertama adalah disepakati nama UMKM yaitu "Kedele Cryspy Erte" dari nama ini dihasilkan sebuah desain logo UMKM dan kemasan produk yang mencirikan produk hasil UMKM mitra. Desain dan tampilan yang baru dapat mengubah perspektif konsumen dan pangsa pasar produk. Pendapat ini sejalan dengan dengan pendapat Kotler dan Amstrong (dalam Wijaya, 2009) yang menyampaikan inovasi dalam kemasan dapat memiliki nilai lebih dalam sebuah persaingan pasar. Sebelumnya mitra hanya mengemas produk kedelai secara sederhana dan memasarkan ke pasar tradisional, sekarang kemasan menjadi lebih higenis, dan menarik. Dan yang tidak kalah penting, pemasaran selain dilakukan secara konvensional atau berjualan ke pasar tradisional juga dilakukan dengan memanfaatkan media daring.

Hasil kedua yang dicapai adalah dihasilkan sebuah olahan produk kedelai berupa kedelai krispi. Produk ini merupakan merupakan hasil inivasi dari produk mitra sebelumnya 
yang menghasilkan kedelai goreng. Dengan adanya inovasi ini diharapkan dapat meningkatkan nilai ekonomis produk dan pasar produk. Produk yang dihasilkan memiliki kelebihan diantaranya: penggunaan minyak goreng bisa diminimalisir, sehingga dapat menghemat biaya dan lebih menyehatkan, kemasan efektif, yang membuat produk lebih tahan lama. Gambar produk disajikan pada gambar 1. Inovasi olahan kedelai pada mitra memberikan dampak yang positif bagi mitra. Omset yang didapatkan oleh mitra mengalami kenaikan sebesar $20 \%$ pada minggu pertama dan kedua pada saat dilakukan uji coba pemasaran. Kenaikan ini dianalisa setelah dibandingkan dengan perolehan pendapatan pada setiap minggu.

Hasil ketiga yaitu didapatkan izin produk industri rumah tangga (PIRT) yang dikeluarkan oleh Dinas Kesehatan Kabupaten Ponorogo untuk menjamin keamanan dari produk olahan mitra. Hasil keempat yaitu dikeluarkannya Hak Cipta buku panduan inovasi produk bahan dasar kedelai. Dan hasil kelima, yaitu dihasilkan media promosi yang dikelo oleh mitra untuk melakukan promosi ataupun transaksi jual beli produk secara online. Berikut diuraikan deskripsi hasil pelaksanaan program.

Identifikasi masalah dan sosialiasi program kegiatan yang hasilnya didapatkan beberapa permasalahan yang dimiliki oleh mitra, yaitu: produksi olahan kedelai dilakukan secara tradisional, kemasan sangat sederhana, belum ada ijin usaha dan PIRT, dan pemasaran hanya dilakukan di pasar tradisional. Temuan lain yang juga berdampak pada kemajuan usaha yaitu lokasi temapat usaha berada di dalam atau tidak berada pada posisi yang strategis. Dari temuan ini tim Abdimas melaksanakan program sesuai temuan masalah dan perencanaan program sesuai pada bagian metode. Sosialisasi dilakukan dengan tujuan untuk mempermudah pelaksanaan program dan diperolehnya kejelasan oleh mitra dan pihak terkait tentang program yang akan dijalankan. Dari kegiatan sosialisasi ini didapatkan hasil yaitu dukungan dari pihak pemerintah setempat untuk melaksanakan kegiatan dan berharap kegiatan ini dapat dikembangkan pada subyek yang lebih luas, bukan hanya pada mitra.

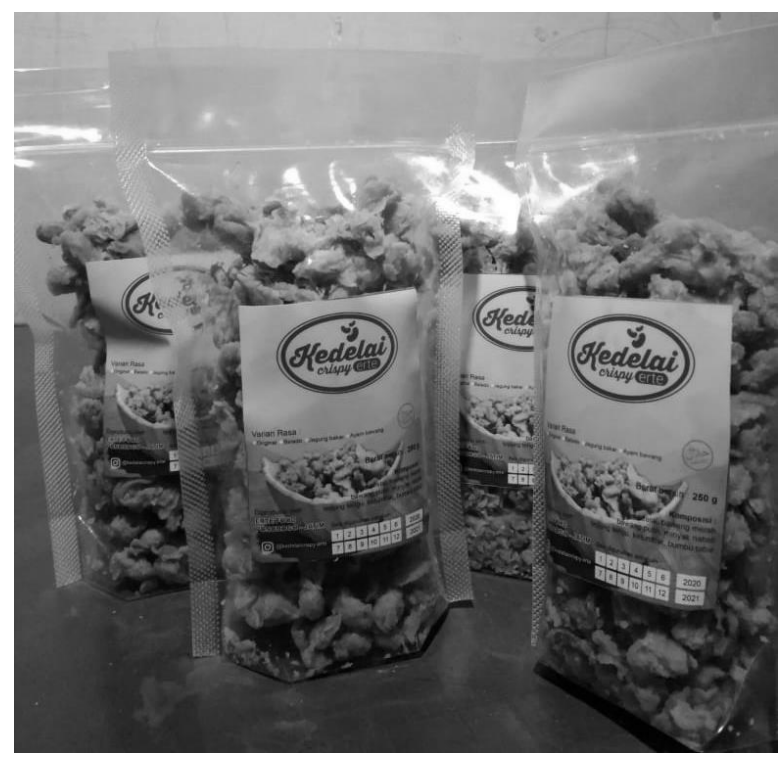

Gambar 1. Produk Kedele Cryspy Erte (Hasil Produksi Mitra Abdimas)

Pelaksanaan sosialisasi sekaligus dilaksanakan kegiatan Studi kelayakan melalui FGD. Pihak yang dihadirkan dalam kegiatan FGD adalah ahli dalam bidang kewirausahaan (membantu memberikan masukan untuk proses analisis SWOT), bidang kesehatan (untuk menghasilkan produk yang aman untuk dikonsumsi). Hasil dari kegiatan FGD diperoleh masukan dari pakar kewirausahaan, yaitu: melakukan modifikasi nama UMKM, dari nama 
awal "ERTE Kripik Tempe" menjadi "Kedelai Ceyspy Erte". Perubahan nama ini sekaligus memberikan tambahan produk baru dari mitra, yang sebelumnya menghasilkan kedelai goreng dan kripik tempe, sekarang bertambah menjadi kedelai krispi yang rendah kolesterol. Pergantian nama ini sekaligus untuk melakukan branding produk yang dapat mempengaruhi daya tarik atau minat beli konsumen (Supriyadi, Fristin, \& K.N, 2016).

Setelah pelaksanaan FGD tahapan berikutnya yaitu melaksanakan pelatihan dan pendampingan kepada mitra. Pelatihan dan pendampingan secara intensif dilaksanakan sebanyak 4 (empat) kali selama 2 bulan. Hasil dari tahapan ini, diantaranya: dihasilkan 1 (satu) produk baru dari mitra yaitu kedelai krispi rendah kolesterol. Produk baru ini direncakan menjadi produk unggulan dari mitra yang dapat menarik minat beli konsumen dan meningkatkan pendapatan mitra. Hasil kedua, yaitu didapatkan desain kemasan produk yang menarik dan higienis serta logo baru produk mitra. Tampilan kemasan ini dapat mempengaruhi masyarakat untuk membeli produk (Arifudin, Rusmana, Tanjung, \& Wahrudin, 2020). Dengan adanya penciri ini harapanya produk mitra mudah dikenal oleh masyarakat luas. Dan hasil ketiga yang diperoleh pada tahap ini adalah strategi pemasaran yang kreatif dan inovatif yang dilakukan secara online maupun offline. Pemasaran secara online dipilih dengan tujuan untuk meningkatkan daya saing UMKM (Ismanto, Tamrin, \& Edward, 2020). Strategi pemasaran ini sangat berpengaruh terhadap minat beli konsumen sehingga perlu diperhatikan dan dilakukan semenarik mungkin untuk mempengaruhi daya Tarik pembeli (Firdaus, 2017; Sumaila, Dumais, \& Tangkere, 2018).

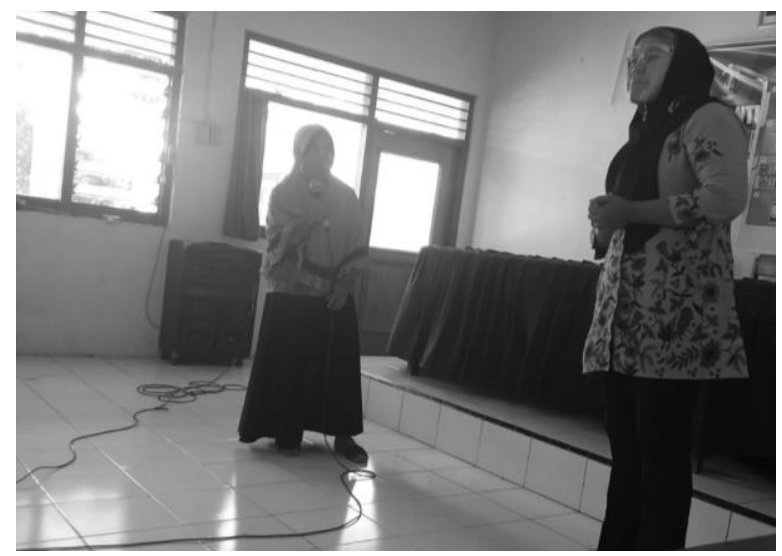

Gambar 2. Dokumentasi Kegiatan Sosialiasi Program Abdimas

Tahapan yang dilaksanakan setelah semua program berjalan yaitu melaksanakan monitoring dan evaluasi sebagai bentuk tindak lanjut/follow up, kegiatan ini dilaksanakan setiap 2 minggu untuk memastikan keberlangsungan program dan melihat apakah mitra memiliki permasalahan selama menjalankan usahannya. Temuan pada monitoring pertama, mitra masih mengalami kendala terkait pemanfaatan media online untuk melakukan transaksi dan cara pengolahan produk kedelai crispi masih belum bisa maksimal, seperti masih ada kedelai yang gosong. Dari temuan ini tim Abdimas kembali memberikan pendampingan untuk mengatasi masalah yang ada. Kegiatan monitoring dilakukan selain mengetahui masalah mitra juga untuk menjamin kualitas produk dari mitra. Pendapat ini sejalan dengan hasil penelitian dari Rahmayani \& Haryanto (2018) dan Sari \& Purnawati (2018) yang hasil penelitiannya menunjukan jika control dari supervisor mempengaruhi hasil produksi.

Program kegiatan yang telah terlaksana, secara keseluruhan berjalan dengan baik dan mendapat respon positif dari mitra maupun pemerintah setempat. Pemerintah setempat berharap ada kegiatan lanjutan untuk membangun UMKM lain yang bertujuan meningkatkan pendapatan masyarakat sekitar. Capaian nyata dari program ini yaitu meningkatkan kualitas 
produksi dari mitra dan memberikan dampak ekonomi yang baik bagi masyarakat sekitar. Selaian capaian ini, ada 3 (tiga) luaran lain yang dihasilkan, diantaranya: publikasi pada media masa, dihasilkannya buku panduan berwirausaha kedelai, dan diperolehnya Hak cipta (Buku Panduan Inovasi Produk Bahan Dasar Kedelai).

Keberhasilan dari program ini salah satunya tidak terlepas dari kontribusi atau dukungan pemerintah setempat. Dukungan ini terwujud dari, ijin pelaksanaan kegiatan, ijin peminjaman lokasi sosialiasi program dan memfasilitasi kader PKK untuk terlibat aktif pada kegiatan ini. Keterlibatan Masyarakat sangat mendukung kegiatan ini sejalan dengan pendapat Ulumiyah, Gani, \& Mindarti (2013) yang menyatakan pemberdayaan penduduk dapat terlaksana jika pemerintah setempat memliki peran aktif. Aspek lain selain pemerintah yang ikut berkontribusi yaitu Masyarakat itu sendiri. Hadi (2015) menyatakan warga masyarakat yang diberdayakan dengan baik akan dapat mendukung ketercapaian program. Dua aspek ini tentunya akan menjadi aspek yang saling mendukung keberhasilan sebuah program. Program pemberdayaan masyarakat juga sangat dibutuhkan oleh masyarakat, baik yang masih produktif maupun non produktif seperti lansia (Zahroni, Andriani, Helmastuti, \& Kadafi, 2019). Hasil program ini diharapkan kedepan dapat memberikan dampak pada peningkatan perekonomian di masyarakat luas dan tentunya mitra dapat mengembangkan usaha yang berimbas pada penyerapan tenaga kerja dari warga sekitar

\section{KESIMPULAN}

Program abdimas ini memberikan dampak nyata pada peningkatan perekonomian mitra. Luaran yang telah dicapai dari program ini antara lain: diperolehnya izin UMKM, izin PIRT, nama dan desain produk, strategi pemasaran yang inovatif. Program ini hanya bermitra dengan 1 (satu) UMKM yang menjadi poin kelebihan dan kekurangan program ini. Kelebihan yang ada, tim Abdimas dapat fokus untuk membantu pengembangan usaha mitra, dan kelemahannya yaitu program ini belum bisa menjangkau masyarakat luas. Dari kekurangan yang ada, diharapkan kedepan Tim Abdimas dan pemerintah setempat bekerjasama untuk membangun kegiatan serupa guna memperbaiki tingkat perekonomian warga masyarakat.

\section{UCAPAN TERIMA KASIH}

Ucapan terimakasih kami sampaikan kepada pihak LPPM Universitas PGRI Madiun yang telah membantu pembiayaan program ini. Selain itu, tim juga menyampaikan terimakasih kepada pihak pemerintah Desa Nambak yang telah memfasilitasi kegiatan in.

\section{DAFTAR PUSTAKA}

Arifudin, O., Rusmana, F. D., Tanjung, R., \& Wahrudin, U. (2020). Inovasi Kemasan Dan Perluasan Pemasaran Dodol Nanas Di Subang Jawa Barat. DINAMISIA: Jurnal Pengabdian Kepada Masyarakat, 4(3), 408-417. Retrieved from https://journal.unilak.ac.id/index.php/dinamisia/article/view/4469/2312

Firdaus, A. (2017). Pengaruh Strategi Pemasaran terhadap Minat Konsumen Membeli Produk Perumahan. JOM FISIP, 4(1), 1-12. Retrieved from https://media.neliti.com/media/publications/130504-ID-pengaruh-strategi-pemasaranterhadap-min.pdf

Hadi, A. P. (2015). Konsep pemberdayaan, partisipasi dan kelembagaan dalam pembangunn. Pusat Pengembangan Masyarakat Agrikarya. 
Irham, M. (2020, March 19). Virus corona: UMKM diterjang pandemi Covid-19 sampai 'kembang kempis. BBC News Indonesia. Retrieved from https://www.bbc.com/indonesia/indonesia-51946817

Ismanto, H., Tamrin, M. H., \& Edward, M. Y. (2020). Pendampingan UKM Tenun Ikat Troso dalam Pengelolaan Model Pemasaran Berbasis Online. E-DIMAS: EDUCATIONPENGABDIAN KEPADA MASYARAKAT, 11(1), 87-95. Retrieved from http://journal.upgris.ac.id/index.php/e-dimas/article/view/2744

Rahmayani, L., \& Haryanto, H. (2018). Rancang Bangun Aplikasi Monitoring Laporan Quality Control Dan Defective Produksi Sepatu Berbasis Web (Studi Pada Pt. Panarub Industry). Jurnal Teknik Informatika UNIS, 6(2), 76-81. Retrieved from http://ejournal.unis.ac.id/index.php/jutis/article/view/132

Sari, N. K. R., \& Purnawati, N. K. (2018). Analisis Pengendalian Kualitas Proses Produksi Pie Susu Padaperusahaan Pie Susu Barong di Kota Denpasar. E-Jurnal Manajemen Unud, 7(3), 1566-1594. Retrieved from https://core.ac.uk/download/pdf/207018055.pdf

Sumaila, D. O., Dumais, J. N. K., \& Tangkere, E. G. (2018). Pengaruh Strategi Pemasaran terhadap Keputusan Pembelian Ulang pada Produk Share Tea di Manado Town Square 3 Kota Manado. Agri-Sosio Ekonomi Unsrat, 14(2), 67-76. Retrieved from https://ejournal.unsrat.ac.id/index.php/jisep/article/view/20325

Supriyadi, Fristin, Y., \& K.N, G. I. (2016). Pengaruh Kualitas Produk dan Brand Image terhadap Keputusan Pembelian. Jurnal Bisnis Dan Manajemen, 3(1), 135-144. Retrieved from https://media.neliti.com/media/publications/75449-ID-pengaruh-kualitas-produkdan-brand-image.pdf

Ulumiyah, I., Gani, A. J. G., \& Mindarti, L. I. (2013). Peran Pemerintah Desa dalam Memberdayakan Masyarakat Desa (Studi pada Desa Sumberpasir Kecamatan Pakis Kabupaten Malang). Jurnal Administrasi Publik.

Wijaya, T. (2009). Analisis Persepsi Konsumen terhadap Produk Private Label di PT Lion Super Indo Jakarta. Jurnal Ilmiah Manajemen Bisnis, 9(2), 95-118. Retrieved from https://media.neliti.com/media/publications/97680-ID-analisis-persepsi-konsumenterhadap-prod.pdf

Zahroni, P. K. D., Andriani, I., Helmastuti, F., \& Kadafi, A. (2019). Optimalisasi peran Lansia dalam meningkatkan perekonomian keluarga melalui pelatihan pembuatan getuk beton. Prosiding SNBK: Seminar Nasional Bimbingan Dan Konseling, 78-83. Retrieved from http://prosiding.unipma.ac.id/index.php/SNBK/article/view/876 